\title{
Klasifikasi Tingkat Gangguan Tidur Menggunakan Algoritma Naïve Bayes
}

\author{
Iwan Ady Prabowo 1); Dwi Remawati ${ }^{2}$; Aji Pratama Wisnu Wardana ${ }^{3)}$ \\ ${ }^{1,3)}$ Program Studi Informatika, STMIK Sinar Nusantara \\ 2) Program Studi Teknologi Informasi, STMIK Sinar Nusantara \\ 1) iwanady@sinus.ac.id; ${ }^{2)}$ dwirema@sinus.ac.id; ${ }^{3)}$ wardana02@gmail.com
}

\begin{abstract}
The Sleep disorder sometimes happens to someone unconsciously. Many health worker need a lot of time to detect the cause of sleep disorder, it is because there are some similar type of sleep disorder. The public health center in Karangmalang Sragen is needed a system to help the health workers to analyze the cause of sleep disorders. The aim of this research is to make a system to analyze the cause of sleep disorder by using the Naïve Bayes method. This research is conducted on Integrated Healthcare Center especially for the elderly in kedungwaduk. This research chooses the Naïve Bayes method to analyzing the type of sleep disorder experiences happen by the patient. The types of sleep disorders that used in this study were insomnia, hypersomnia, narcolepsy, sleep terror, disturbed sleep schedules and nightmares. The result in this study is patients can get solution about their sleep disorder, and also it can reduce the bad effect for the patient. The validation result of the Naïve Bayes method showed that $80 \%$ data was accuracy and it will be compared between 10 data from diagnostic test and 30 testing data.
\end{abstract}

Keywords : Sleep disturbance, diagnosis, naïve bayes

\section{PENDAHULUAN}

Kebutuhan hidup memaksa manusia bekerja untuk mencukupi kehidupan sehari hari. Pada umumnya manusia bekerja pada siang hari dan istirahat dimalam hari. Kurang tidur merupakan suatu hal yang krusial dalam pola hidup. Kualitas tidur yang baik akan membuat metabolisme tubuh seimbang, sebaliknya jika kualitas tidur seseorang buruk maka akan berpengaruh terhadap kondisi tubuhnya. Efek gangguan tidur juga menurunkan kualitas hidup, kurang tidur juga mempengaruhi emosi manusia dan sistem metabolisme tubuh.

Dari hasil wawancara dengan tenaga kesehatan di Puskesmas Karangmalang dan tenaga kesehatan yang berada di Posyandu Wilayah Puskesmas Karangmalang, pada saat dilakukan kegiatan pemeriksaan terdapat pasien yang terindikasi mengalami gangguan tidur, tetapi gejala yang terjadi pada gangguan tidur sangat mirip, sehingga tenaga kesehatan mengalami kesulitan dalam mendeteksi kejadian gangguan tidur yang dialami oleh pasien.

Dengan kemajuan teknologi komunikasi yang ada, siapa saja dapat mengakses informasi sesuai kebutuhannya. Untuk mengetahui tingkat gangguan tidur menggunakan sebuah sistem, dibutuhkan data untuk diolah dan di klasifikasikan setiap tingkatan gangguannya. Sehingga seorang tenaga kesehatan atau atau bidan yang melakukan kunjungan nifas kepada pasiennya dapat terbantu dengan adanya sebuah sistem yang mampu melakukan diagnosis terhadap tingkat gangguan tidur yang dialami. Salah satu metode yang dapat diterapkan dalam permasalahan ini adalah Naive bayes. Menurut A. Fadhli Almuiin and Miftachuniam[1], metode bayes merupakan metode yang baik didalam mesin pembelajaran berdasarkan data training. Naive bayes digunakan untuk memprediksi probabilitas di masa depan berdasarkan pengalaman dimasa sebelumnya. Oleh karena itu penelitian ini bertujuan untuk membuat sistem diagnosis gangguan tidur dengan memanfaatkan metode Naïve Bayes dimana penelitian in dilakukan pada anggota posyandu lansia adem ayem kedungwaduk.

\section{TINJAUAN PUSTAKA}

\subsection{Tidur}

Tidur merupakan sebuah fase penting dalam kegiatan sehari-hari yang bermanfaat untuk menyeimbangkan kehidupan manusia. Tidur amatlah penting bagi kesehatan, fungsi emosional, mental dan keselamatan. Tidur merupakan proses yang amat diperlukan 
bagi manusia untuk terjadinya Natural Healing mechanism (proses pembentukan sel sel tubuh yang rusak), memberi waktu untuk beristirahat ataupun menjaga keseimbangan metabolisme dan biokimiawi tubuh [2].

\subsection{Kebutuhan Tidur}

Tidur merupakan proses yang amat diperlukan bagi manusia untuk terjadinya proses pembentukan sel sel tubuh yang rusak "Natural Healing Mechanism", memberi waktu untuk beristirahat ataupun menjaga keseimbangan metabolisme dan biokimiawi tubuh [2].Manusia memiliki waktu tidur yang berbeda bedasarkan klasifikasi usia. Dalam kelompok usia didapatkan perbedaan yang besar antara individu mengenai kebutuhan tidur. Berikut tabel kebutuhan tidur berdasarkan klasifikasi usia:

Tidur kurang dari 6 jam semalam, pada umumnya mengakibatkan gejala deprivasi (kurang) tidur. Perlu pula diketahui bahwa tidur yang berlebihan dapat mengakibatkan tidur yang tidak menyegarkan dan rasa letih (fatigue) di siang hari.

\subsection{Klasifikasi}

Klasifikasi adalah suatu proses untuk mengelompokkan sejumlah data kedalam kelas-kelas tertentu yang sudah diberikan berdasarkan kesamaan sifat dan pola yang terdapat dalam data-data tersebut. Secara umum, proses klasifikasi dimulai dengan diberikannya sejumlah data yang menjadi acuan untuk membuat aturan klasifikasi data. Data-data inilah yang biasa disebut dengan training sets.

Dari training sets tersebut kemudian dibuat suatu model untuk mengklasifikasi data-data yang belum diketahui kelasnya dan biasa disebut sebagai test sets [4].

\subsection{Klasifikasi Gangguan Tidur}

Gangguan tidur diklasifikasikan berdasarkan "Pedoman Penggolongan Dan Diagnosis Gangguan Jiwa di Indonesia" [2]. Yang merupakan referensi untuk semua dokter dengan pasien gangguan tidur di Indonesia. Edisi ini digunakan sejak tahun 1993 sampai sekarang, yang termasuk nomenklatur, klasifikasi dan diagnosis. Pada PPDGJ III ini gangguan tidur diklasifikasikan menjadi dua kelompok yaitu gangguan tidur organik dan gangguan tidur non organik. Dalam penelitian ini hanya membahas gangguan tidur yang termasuk dalam gangguan tidur non organik. Gangguan tidur ini adalah insomnia, hipersomnia, narkolepsi, gangguan jadwal tidur, teror tidur, dan mimpi buruk.

\subsection{Metode Naïve Bayes}

Naïve Bayes merupakan pengklasifikasi probabilitas sederhana berdasarkan pada teorema Bayes. Teorema Bayes dikombinasikan dengan "Naïve" yang berarti setiap atribut/variabel bersifat bebas (independent).Naïve Bayes dapat dilatih dengan efisien dalam pembelajaran terawasi (supervised learning). Keuntungan dari klasifikasi adalah bahwa ia hanya membutuhkan sejumlah kecil data pelatihan untuk memperkirakan parameter (sarana dan varians dari variabel) yang diperlukan untuk klasifikasi. Karena variabel independen diasumsikan, hanya variasi dari variabel untuk masing-masing kelas harus ditentukan, bukan seluruh matriks kovarians [5].

Bayes rule digunakan untuk menghitung probabilitas suatu class. Algoritma Naive Bayes memberikan suatu cara mengkombinasikan peluang terdahulu dengan syarat kemungkinan menjadi sebuah formula yang dapat digunakan untuk menghitung peluang dari tiap kemungkinan yang terjadi. Bentuk umum dari teorema bayes seperti dibawah ini [6]:

$$
P(H \mid X) \frac{P(H \mid X) P(H)}{P(X)}
$$

Dimana:

$X$ :Data dengan class yang belum diketahui

$\mathrm{H}$ :Hipotesis data $\mathrm{X}$ merupakan suatu class spesifik.

$\mathrm{P}(\mathrm{H} \mid \mathrm{X})$ :Probabilitas hipotesis $\mathrm{H}$ berdasar kondisi $\mathrm{X}$ ( posteriori probability)

$\mathrm{P}(\mathrm{H}) \quad$ :Probabilitas hipotesis $\mathrm{H}$ (prior probability)

$\mathrm{P}(\mathrm{X} \mid \mathrm{H})$ :Probabilitas $\mathrm{X}$ berdasar kondisi pada hipotesis $\mathrm{H}$

$\mathrm{P}(\mathrm{X})$ :Probabilitas dari $\mathrm{X}$

\subsection{UML}

UML adalah salah satu standar bahasa yang banyak digunakan di dunia industri untuk mendefinisikan requirement, membuat analisis dan desain, serta menggambarkan 
arsitektur dalam pemrograman berorientasi objek [6].

\section{Use Case Diagram}

Use case diagram pada umumnya tersusun dari elemen actor, use case, dependency, generalization, dan asociation. UCD ini memberikan gambaran statis dari sistem yang sedang dibangun dan merupakan artifak dari proses analisis [6].

\section{Class Diagram}

Class diagram atau diagram kelas merupakan suatu diagram yang menggambarkan struktur sistem dari segi pendefinisian kelas-kelas yang akan dibuat untuk membangun sistem. Kelas memiliki apa yang disebut atribut dan metode atau operasi [6].

\section{Sequence Diagram} Sequence diagram menjelaskan secara detail urutan proses yang dilakukan dalam sistem untuk mencapai tujuan dari use case: interaksi yang terjadi antar class, operasi apa saja yang terlibat, urutan antar operasi, dan informasi yang diperlukan oleh masing-masing operasi. Pembuatan sequence diagram merupakan aktivitas yang paling kritikal dari proses desain karena artifak inilah yang menjadi pedoman dalam proses pemrograman nantinya dan berisi aliran kontrol dari program [6].

\section{Activity Diagram}

Activity diagram menggambarkan workflow atau aktivitas dari sebuah sistem atau proses bisnis. Yang perlu diperhatikan disini bahwa diagram aktivitas menggambarkan aktivitas sistem bukan apa yang dilakukan aktor, jadi aktivitas yang dapat dilakukan sistem [6].

\section{METODE PENELITIAN}

Metode penelitian dalam penelitian ini menggunakan metode exsperimental dengan menerapkan Metode pengembangan sistem model waterfall, dimana metode pengembangan ini dibagi menjadi lima tahapan yaitu analisis sistem, desain sistem, pengkodean/ coding, testing dan implementasi sistem

\subsection{Analisis Sistem}

Tahap analisis sistem ini terdapat proses pengumpulan data yang dilakukan dengan proses observasi dari buku, jurnal ataupun dokumen serta proses wawancara digunakan untuk mendapatkan data mengenai gangguan tidur pada puskesmas karangmalang sragen

\subsection{Desain Sistem}

Desain sistem klasifikasi tingkat gangguan tidur ini menggunakan UML. Terdiri dari use case diagram, activity diagram, sequence diagram dan class diagram.

\subsection{Pengkodean/koding}

Dalam pembuatan aplikasi berbasis web menggunakan bahasa pemrograman PHP.

\subsection{Testing}

Testing atau Pengujian sistem dengan metode black box dan uji validitas.

\subsection{Implementasi sistem}

Implementasi program berisi paparan gambar asli dari sistem yang dikerjakan dengan masalah mengenai diagnosa gangguan tidur

\section{HASIL DAN PEMBAHASAN}

\subsection{Perhitungan Naïve Bayes}

Studi kasus penggunaan naïve bayes pada diagnosa gangguan tidur pada seorang pasien dilakukan dengan mendapatkan data 6 jenis gangguan tidur dapat dilihat pada tabel 1 dan 31 gejala dan data gejala dapat dilihat pada tabel 2 dan 3 yang dimiliki oleh masing-masing jenis gangguan tidur, dimana data tersebut didapat langsung dari tenaga kesehatan yang bertugas di posyandu di wilayah kerja puskesmas karangmalang, sragen. Kemudian terdapat pula 30 data pasien dapat dilihat pada tabel 4 yang diolah menjadi data training sebagai basis perhitungan dari metode Naïve Bayes.

Tabel 1 Tabel Jenis Gangguan Tidur

\begin{tabular}{|l|l|}
\hline Kode Gangguan & Jenis Gangguan \\
\hline P01 & Insomnia \\
\hline P02 & Hipersomnia \\
\hline P03 & Narkolepsi \\
\hline P04 & Gangguan Jadwal Tidur \\
\hline P05 & Teror Tidur \\
\hline
\end{tabular}

Tabel 2 Tabel Gejala

\begin{tabular}{|c|l|}
\hline $\begin{array}{c}\text { Kode } \\
\text { Gejala }\end{array}$ & \multicolumn{1}{|c|}{ Nama Gejala } \\
\hline G01 & $\begin{array}{l}\text { Sulit tidur atau kesulitan } \\
\text { mempertahankan tidur. }\end{array}$ \\
\hline G02 & $\begin{array}{l}\text { Merasa tegang, cemas, khawatir, atau } \\
\text { tertekan saat tidur. }\end{array}$ \\
\hline G03 & $\begin{array}{l}\text { Merasa Kelelahan yang } \\
\text { berkepanjangan. }\end{array}$ \\
\hline G04 & $\begin{array}{l}\text { Saat terbangun mengalami hilangnya } \\
\text { konsentrasi dan daya ingat }\end{array}$ \\
\hline
\end{tabular}




\begin{tabular}{|c|c|}
\hline $\begin{array}{l}\text { Kode } \\
\text { Gejala }\end{array}$ & Nama Gejala \\
\hline G06 & $\begin{array}{l}\text { Membutuhkan tenggang waktu yang } \\
\text { lebih lama untuk mencapai keadaan } \\
\text { siaga penuh saat bangun tidur }\end{array}$ \\
\hline G07 & $\begin{array}{l}\text { Merasakan kantuk berlebihan pada } \\
\text { siang hari }\end{array}$ \\
\hline G08 & $\begin{array}{l}\text { Mengalami Serangan tidur/kantuk tak } \\
\text { tertahankan }\end{array}$ \\
\hline$\ldots$ & $\ldots \ldots \ldots$ \\
\hline G24 & Sakit kepala dan kepala terasa tegang \\
\hline G25 & Rasa tertekan di perut dan usus \\
\hline G26 & Kekhawatiran tentang tidur \\
\hline G27 & Sedang sakit dan menderita demam \\
\hline G28 & Sedang menjalani proses pengobatan \\
\hline G29 & Mengalami hal yang menyeramkan \\
\hline G30 & $\begin{array}{l}\text { Kecemasan karena mengalami } \\
\text { perubahan-perubahan baru dalam } \\
\text { kehidupan }\end{array}$ \\
\hline G31 & $\begin{array}{l}\text { Menggerakkan tangan dan kaki serta } \\
\text { kadang-kadang berjalan saat tidur }\end{array}$ \\
\hline
\end{tabular}

Tabel 3 Tabel Gangguan Tidur dan Gejalanya

\begin{tabular}{|c|c|c|c|c|c|c|}
\hline \multirow{2}{*}{ Kode } & \multicolumn{6}{|c|}{ Kode Jenis Gangguan Tidur } \\
\hline & P0jala & P0 & P0 & P0 & P0 & P0 \\
& $\mathbf{1}$ & $\mathbf{2}$ & $\mathbf{3}$ & $\mathbf{4}$ & $\mathbf{5}$ & $\mathbf{6}$ \\
\hline G01 & v & & & & & \\
\hline G02 & v & & & & & \\
\hline G03 & v & v & & & & \\
\hline G04 & v & & & & & \\
\hline G05 & & v & v & v & & \\
\hline G06 & & v & & & & \\
\hline G07 & & & v & & & \\
\hline$\ldots$ & $\ldots$ & $\ldots$ & $\ldots$ & $\ldots$ & $\ldots$ & $\ldots$ \\
\hline G23 & v & & & & & \\
\hline G24 & v & & & & & \\
\hline G25 & v & & & & & \\
\hline G26 & & $v$ & & & & v \\
\hline G27 & & & & & & v \\
\hline G28 & & & & & & v \\
\hline G29 & & & & & & v \\
\hline G30 & & & & & & v \\
\hline G31 & & & & & v & \\
\hline
\end{tabular}

Tabel 4 Tabel Data Pasien Posyandu Kedungwaduk

\begin{tabular}{|l|l|l|l|}
\hline No & PASIEN & GEJALA & DIAGNOSA \\
\hline 1 & Pasien 01 & $\begin{array}{l}\text { G01,G04,G07,G0 } \\
8,\end{array}$ & $\begin{array}{l}\text { P01- } \\
\text { Insomnia }\end{array}$ \\
\hline 2 & Pasien 02 & $\begin{array}{l}\text { G01,G04,G07,G0 } \\
8,\end{array}$ & $\begin{array}{l}\text { P01- } \\
\text { Insomnia }\end{array}$ \\
\hline 3 & Pasien 03 & $\begin{array}{l}\text { G05,G15,G24,G1 } \\
\text { 2,G31, }\end{array}$ & $\begin{array}{l}\text { P05-Teror } \\
\text { Tidur }\end{array}$ \\
\hline 4 & Pasien 04 & $\begin{array}{l}\text { G03,G0 } \\
6, G 08,\end{array}$ & $\begin{array}{l}\text { P02- } \\
\text { Hipersomnia }\end{array}$ \\
\hline
\end{tabular}

\begin{tabular}{|c|c|c|c|}
\hline No & PASIEN & GEJALA & DIAGNOSA \\
\hline 5 & Pasien 05 & $\begin{array}{l}\text { G01,G13,G11,G0 } \\
7,\end{array}$ & $\begin{array}{l}\text { P01- } \\
\text { Insomnia }\end{array}$ \\
\hline 6 & Pasien 06 & $\begin{array}{l}\text { G02,G04,G07,G1 } \\
\text { 3,G22, G30,G28, }\end{array}$ & $\begin{array}{l}\text { P01- } \\
\text { Insomnia }\end{array}$ \\
\hline 7 & Pasien 07 & $\mathrm{G} 01, \mathrm{G} 04, \mathrm{G} 08$ & $\begin{array}{l}\text { P01- } \\
\text { Insomnia }\end{array}$ \\
\hline 8 & Pasien 08 & $\begin{array}{l}\text { G01,G04,G07,G0 } \\
8,\end{array}$ & $\begin{array}{l}\text { P01- } \\
\text { Insomnia }\end{array}$ \\
\hline 9 & Pasien 09 & $\begin{array}{l}\text { G01,G04,G07,G0 } \\
8,\end{array}$ & $\begin{array}{l}\text { P01- } \\
\text { Insomnia }\end{array}$ \\
\hline 10 & Pasien 10 & $\begin{array}{l}\text { G05,G15, } \\
\text { G24,G12,G31, }\end{array}$ & $\begin{array}{l}\text { P05-Teror } \\
\text { Tidur }\end{array}$ \\
\hline 11 & Pasien 11 & G03,G06,G08, & $\begin{array}{l}\text { P02- } \\
\text { Hipersomnia }\end{array}$ \\
\hline 12 & Pasien 12 & $\begin{array}{l}\text { G01,G13,G11,G0 } \\
7,\end{array}$ & $\begin{array}{l}\text { P01- } \\
\text { Insomnia }\end{array}$ \\
\hline 13 & Pasien 13 & $\begin{array}{l}\text { G02,G04,G07,G1 } \\
3, \mathrm{G} 22, \mathrm{G} 30, \mathrm{G} 28\end{array}$ & $\begin{array}{l}\text { P01- } \\
\text { Insomnia }\end{array}$ \\
\hline 14 & Pasien 14 & $\mathrm{G} 01, \mathrm{G} 04, \mathrm{G} 08$ & $\begin{array}{l}\text { P01- } \\
\text { Insomnia }\end{array}$ \\
\hline 15 & Pasien 15 & $\begin{array}{l}\text { G14,G21,G17,G2 } \\
3,\end{array}$ & $\begin{array}{l}\text { P01- } \\
\text { Insomnia }\end{array}$ \\
\hline 16 & Pasien 16 & G23,G30,G27, & $\begin{array}{l}\text { P06-Mimpi } \\
\text { Buruk }\end{array}$ \\
\hline 17 & Pasien 17 & $\begin{array}{l}\text { G31,G24,G21,G2 } \\
7,\end{array}$ & $\begin{array}{l}\text { P01- } \\
\text { Insomnia }\end{array}$ \\
\hline 18 & Pasien 18 & $\mathrm{G} 14, \mathrm{G} 09, \mathrm{G} 11$, & $\begin{array}{l}\text { P02- } \\
\text { Hipersomnia }\end{array}$ \\
\hline 19 & Pasien 19 & $\mathrm{G} 17, \mathrm{G} 19, \mathrm{G} 18$ & $\begin{array}{l}\text { P03- } \\
\text { Narkolepsi }\end{array}$ \\
\hline 20 & Pasien 20 & $\begin{array}{l}\text { G24,G22,G27,G2 } \\
8,\end{array}$ & $\begin{array}{l}\text { P01- } \\
\text { Insomnia }\end{array}$ \\
\hline 21 & Pasien 21 & $\begin{array}{l}\text { G24,G22,G27,G2 } \\
8,\end{array}$ & $\begin{array}{l}\text { P01- } \\
\text { Insomnia }\end{array}$ \\
\hline 22 & Pasien 22 & $\begin{array}{l}\text { G27,G29,G17,G3 } \\
0\end{array}$ & $\begin{array}{l}\text { P06-Mimpi } \\
\text { Buruk }\end{array}$ \\
\hline 23 & Pasien 23 & $\begin{array}{l}\text { G15,G22,G08,G2 } \\
0\end{array}$ & $\begin{array}{l}\text { P01- } \\
\text { Insomnia }\end{array}$ \\
\hline 24 & Pasien 24 & G10,G09,G13, & $\begin{array}{l}\text { P01- } \\
\text { Insomnia }\end{array}$ \\
\hline 25 & Pasien 25 & G06,G12,G18, & $\begin{array}{l}\text { P03- } \\
\text { Narkolepsi }\end{array}$ \\
\hline 26 & Pasien 26 & G28,G27,G24, & $\begin{array}{l}\text { P06-Mimpi } \\
\text { Buruk }\end{array}$ \\
\hline 28 & Pasien 28 & $\begin{array}{l}\text { G26,G09,G22,G0 } \\
5\end{array}$ & $\begin{array}{l}\text { P02- } \\
\text { Hipersomnia }\end{array}$ \\
\hline 29 & Pasien 29 & $\begin{array}{l}\text { G10,G25,G23,G1 } \\
2\end{array}$ & $\begin{array}{l}\text { P01- } \\
\text { Insomnia }\end{array}$ \\
\hline 30 & Pasien 30 & G29,G27,G30, & $\begin{array}{l}\text { P06-Mimpi } \\
\text { Buruk }\end{array}$ \\
\hline 31 & Pasien 31 & $\mathrm{G} 01, \mathrm{G} 05, \mathrm{G} 10$ & $\begin{array}{l}\text { P03- } \\
\text { Narkolepsi }\end{array}$ \\
\hline 32 & Pasien 32 & $\begin{array}{l}\text { G01,G12,G03,G0 } \\
6\end{array}$ & $\begin{array}{l}\text { P01- } \\
\text { Insomnia }\end{array}$ \\
\hline
\end{tabular}




\begin{tabular}{|l|l|l|l|}
\hline No & PASIEN & GEJALA & DIAGNOSA \\
\hline 33 & Pasien 33 & G01,G08,G07, & $\begin{array}{l}\text { P03- } \\
\text { Narkolepsi }\end{array}$ \\
\hline 34 & Pasien 34 & G01,G08,G07, & $\begin{array}{l}\text { P03- } \\
\text { Narkolepsi }\end{array}$ \\
\hline 35 & Pasien 35 & G01,G08,G07, & $\begin{array}{l}\text { P03- } \\
\text { Narkolepsi }\end{array}$ \\
\hline 27 & Pasien 27 & $\begin{array}{l}\text { G17,G19,G20,G2 } \\
2\end{array}$ & $\begin{array}{l}\text { P01- } \\
\text { Insomnia }\end{array}$ \\
\hline 28 & Pasien 28 & $\begin{array}{l}\text { G26,G09,G22,G0 } \\
5,\end{array}$ & $\begin{array}{l}\text { P02- } \\
\text { Hipersomnia }\end{array}$ \\
\hline 29 & Pasien 29 & $\begin{array}{l}\text { G10,G25,G23,G1 } \\
\text { 2, }\end{array}$ & $\begin{array}{l}\text { P01- } \\
\text { Insomnia }\end{array}$ \\
\hline 30 & Pasien 30 & G29,G27,G30, & $\begin{array}{l}\text { P06-Mimpi } \\
\text { Buruk }\end{array}$ \\
\hline 31 & Pasien 31 & G01,G05,G10, & $\begin{array}{l}\text { P03- } \\
\text { Narkolepsi }\end{array}$ \\
\hline 32 & Pasien 32 & $\begin{array}{l}\text { G01,G12,G03,G0 } \\
6,\end{array}$ & $\begin{array}{l}\text { P01- } \\
\text { Insomnia }\end{array}$ \\
\hline 33 & Pasien 33 & G01,G08,G07, & $\begin{array}{l}\text { P03- } \\
\text { Narkolepsi }\end{array}$ \\
\hline 34 & Pasien 34 & G01,G08,G07, & $\begin{array}{l}\text { P03- } \\
\text { Narkolepsi }\end{array}$ \\
\hline 35 & Pasien 35 & G01,G08,G07, & $\begin{array}{l}\text { P03- } \\
\text { Narkolepsi }\end{array}$ \\
\hline
\end{tabular}

$\mathrm{n}=1$

$\mathrm{p}=2 / 11=0,1818181818181818$

$\mathrm{m}=32$

$\mathrm{G} 01 \cdot \mathrm{nc}=0$

$\mathrm{G} 02 . \mathrm{nc}=0$

G03.nc $=0$

Gangguan Tidur ke-3 Narkolepsi

$\mathrm{n}=1$

$\mathrm{p}=2 / 11=0,1818181818181818$

$\mathrm{m}=32$

$\mathrm{G} 01 . \mathrm{nc}=0$

$\mathrm{G} 02 . \mathrm{nc}=0$

$\mathrm{G} 03 . \mathrm{nc}=0$

dan seterusnya sampai gangguan tidur ke- 6

2. Menghitung nilai likelihood atau peluang munculnya suatu gejala terhadap suatu jenis gangguan tidur dari masingmasing gejala $P(a 1 / v j)$ dan menghitung nilai $P(v j)$

Gangguan Tidur Insomnia

$$
\begin{gathered}
P(1 \mid \text { in })=\frac{(2+3) * 0,2727272727}{(2+3)}=0,6666666666666667 \\
P(2 \mid \text { in })=\frac{(2+3) * 0,2727272727}{(2+3)}=0,6666666666666667 \\
P(2 \mid \text { in })=\frac{(2+3) * 0,2727272727}{(2+3)}=0,6666666666666667
\end{gathered}
$$

Gangguan Tidur Hipersomnia

$$
\begin{aligned}
& P(1 \mid \mathrm{Hi})=\frac{(0+2) * 0,181818181818}{(0+2)}=0,18188181818 \\
& P(2 \mid \mathrm{Hi})=\frac{(0+2) * 0,181818181818}{(0+2)}=0,18188181818 \\
& P(3 \mid \mathrm{Hi})=\frac{(0+2) * 0,181818181818}{(0+2)}=0,18188181818
\end{aligned}
$$

dan seterusnya sampai jenis gangguan tidur ke-6

3. Menghitung nilai posterior dari tiap jenis gangguan tidur atau nilai probabilitas akhir dengan cara mengalikan nilai prior dengan nilai likelihood $P(a i / v j)$ * $P(v j)$ untuk tiap v (tiap jenis gangguan tidur)

Tahapan perhitungan naïve bayes adalah sebagai berikut :

1. Menentukan nilai prior $(p)$ atau peluang kemunculan suatu gangguan tidur terhadap data training, dimana data training ini adalah data rule antara jenis gangguan tidur dan gejalanya yang telah ditentukan.

Gangguan Tidur ke-1 Insomnia

$\mathrm{n}=1$

$p=3 / 11=0,2727272727272727$

$\mathrm{m}=32$

$\mathrm{G} 01 . \mathrm{nc}=1$

$\mathrm{G} 02 . \mathrm{nc}=1$

G03.nc $=1$

Gangguan Tidur ke-2 Hipersomnia

1. Gangguan Tidur Insomnia

$=\mathrm{P}(\operatorname{In}){ }^{*}\left[\mathrm{P}(1 \mid \ln ){ }^{*} \mathrm{P}(2 \mid \mathrm{In}){ }^{*} \mathrm{P}(3 \mid \mathrm{In})\right]$

$=0.27272727272727 * 0.6666666666 * 0$.

6666666666 * 0.6666666666

$=\mathbf{0 . 0 7 8 4 8 2 7 3}$

2. Gangguan Tidur Hipersomnia

$=\mathrm{P}(\operatorname{In}){ }^{*}\left[\mathrm{P}(1 \mid \ln ){ }^{*} \mathrm{P}(2 \mid \ln ){ }^{*} \mathrm{P}(3 \mid \mathrm{In})\right]$

$=0.18181818181818 * 0.18181818181818$

* 0.18181818181818 * 0.18181818181818

$=0.00065607231374836$

dan seterusnya sampai gangguan tidur ke-6

4. Mencari nilai posterior terbesar sebagai hasil akhir 
Untuk membandingkan pada jenis gangguan tidur mana yang bernilai lebih besar, sehingga nilai yang paling besar tersebutlah yang akan diambil kesimpulan dari perhitungan metode naïve bayes.

Tabel 6 Nilai v dari Hasil Klasifikasi

\begin{tabular}{|l|c|}
\hline Gangguan Tidur & \multicolumn{1}{|c|}{ Nilai v } \\
\hline Insomnia & 0.0015551343733294 \\
\hline Hipersomnia & 0.00065607231374836 \\
\hline Narkolepsi & 0.00065607231374836 \\
\hline $\begin{array}{l}\text { Gangguan Jadwal } \\
\text { Tidur }\end{array}$ & 0.00065607231374836 \\
\hline Teror Tidur & 0.00065607231374836 \\
\hline Mimpi Buruk & 0.00065607231374836 \\
\hline
\end{tabular}

Pada Tabel 6 terlihat Karena nilai 0.0015551343733294 paling besar, maka contoh kasus pasien tersebut diklasifikasikan sebagai jenis gangguan tidur Insomnia.

\subsection{Desain Sistem}

Tahap ini merupakan pengembangan dari sistem dan pembuatan fungsi dengan tujuan yang sudah ditentukan menggunakan UML. Tujuan dari perancangan sistem ini adalah untuk memenui kebutuhan pemakai, serta memberikan gambaran yang jelas kepada developer sistem klasifikasi jenis gangguan tidur dengan metode naïve bayes guna membantu menentukan diagnosa jenis gangguan tidur pada pasien dan dapat mengetahui solusi dari gangguan tidur yang dialami.

\section{Use Case Diagram}

Use Case diagram digunakan untuk memahami sistem dan mengevaluasi bahwa yang dilakukan adalah untuk membantu menyelesaikan proses diagnosis jenis gangguan tidur. Use Case diagram pada sistem diagnosis jenis gangguan tidur ini dapat dilihat pada Gambar 1.

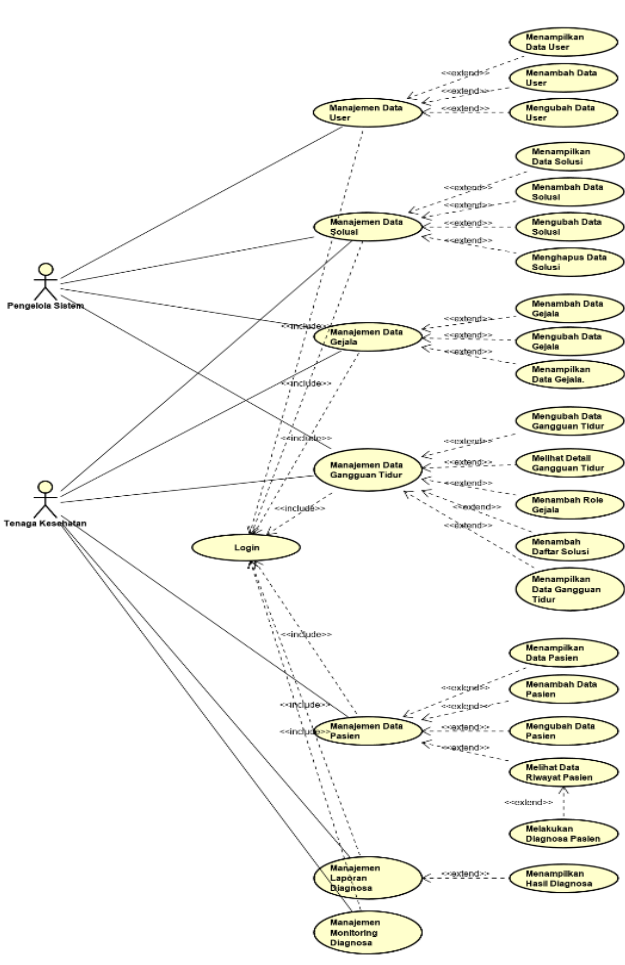

Gambar 1 Use Case Diagram

\section{Class Diagram}

Class Diagram menunjukan hubungan antar class dalam sistem yang dibuat dan bagaimana class tersebut saling berrelasi untuk membuat sebuah proses bisnis yang ada didalam sistem. Berikut Class diagram terlihat pada Gambar 2.

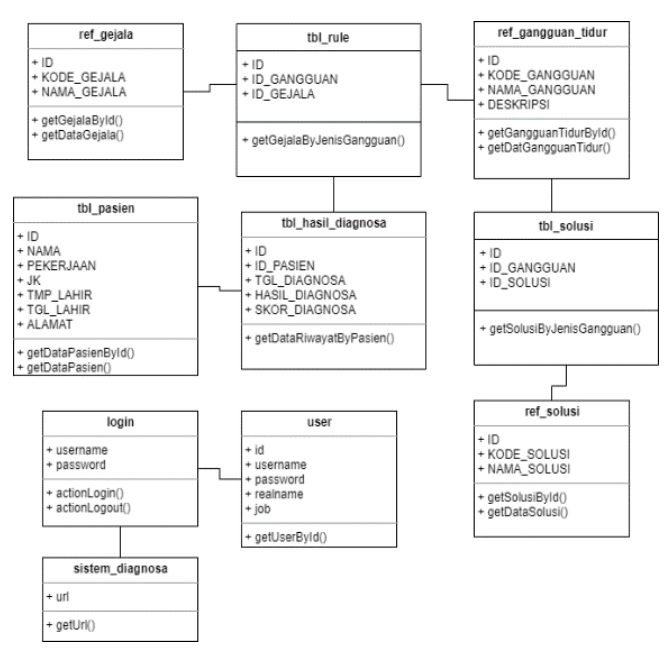

Gambar 2 Class Diagram

\section{Sequence Diagram}

Sequence diagram menjelaskan tentang urutan dari suatu proses pengiriman data yang dilakukan pada proses analisis dalam menentukan diagnosis jenis gangguan tidur yang dialami oleh pasien. Berikut Sequence diagram terlihat pada Gambar 3. 


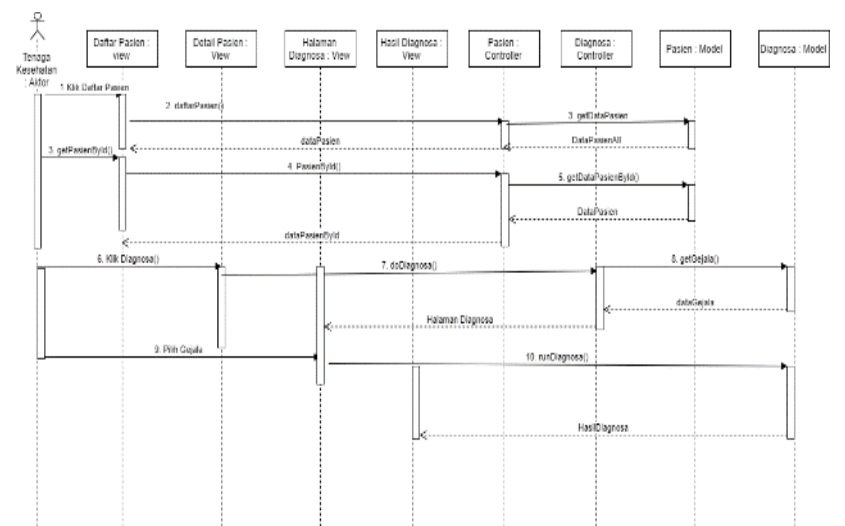

Gambar 3 Sequence Diagram Proses Diagnosis

\section{Activity Diagram}

Activity diagram digunakan untuk menggambarkan aliran kejadian dalam use case sistem dengan tujuan untuk mempermudah dalam menggambarkan setiap aliran dari suatu proses. Proses analisis dalam menentukan diagnosis jenis gangguan tidur pada sistem ini digambarkan dengan activity diagram terlihat pada Gambar 4.

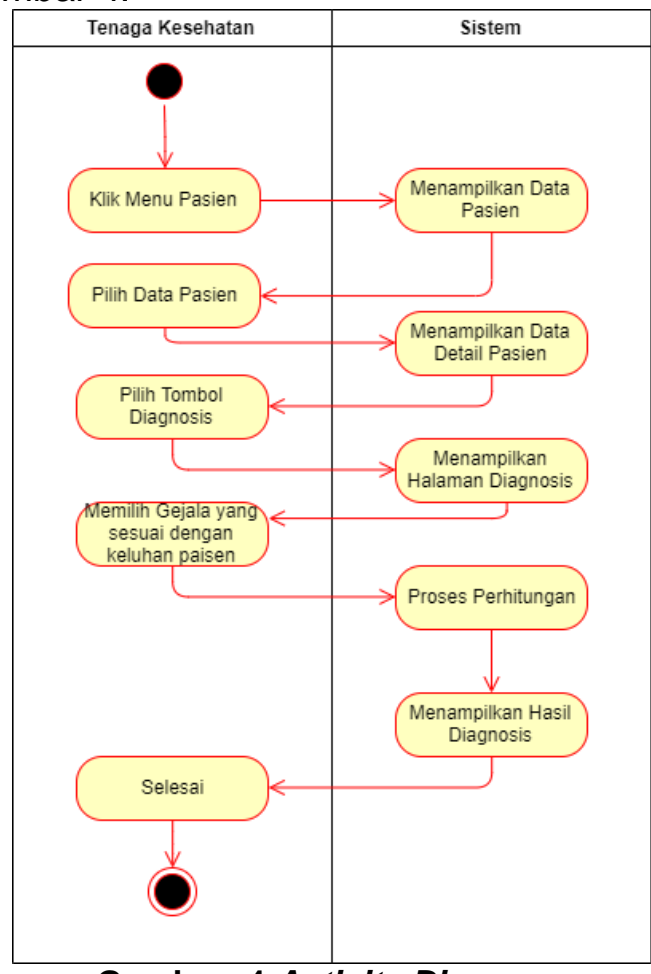

Gambar 4 Activity Diagram

\subsection{Implementasi Sistem}

Implementasi program berisi paparan gambar asli dari sistem yang dikerjakan dengan masalah mengenai diagnosa gangguan tidur.

\section{Halaman Data Pasien}

Halaman data pasien ini memiliki tampilan berbentuk tabel serta terdapat tombol untuk melihat detail lengkap pasien dan tombol untuk melakukan diagnosa jenis gangguan tidur terlihat pada Gambar 5.

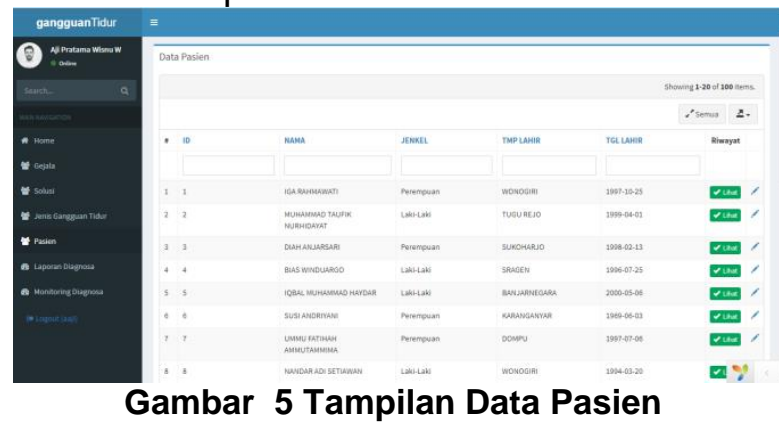

\section{Halaman Diagnosa Pasien}

Halaman diagnosa pasien ini digunakan untuk proses pemilihan gejala yang dialami oleh pasien, yang kemudian akan diolah menggunakan aloritma naïve bayes untuk diagnosis jenis gangguan tidur yang dialami pasien terlihat pada Gambar 6.

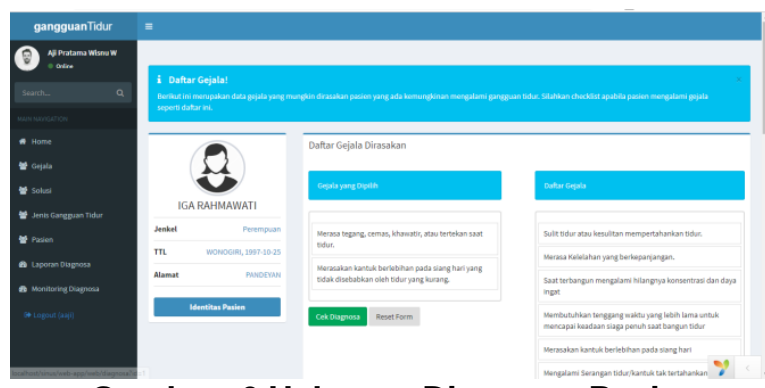

Gambar 6 Halaman Diagnosa Pasien

\section{Halaman Hasil Diagnosa}

Halaman hasil diagnosa ini menampilkan rincihan hasil perhitungan naïve bayes dalam menentukan jenis gangguan tidur yang dialami paisen serta menampilkan deskripsi dari gejala yang dialami pasien terlihat pada Gambar 7.

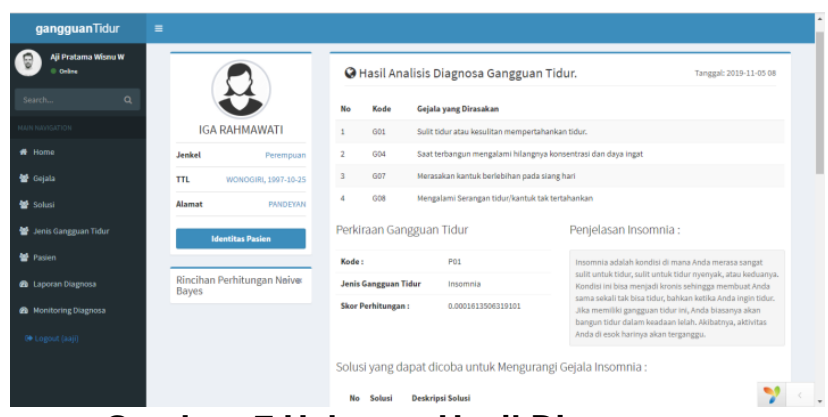

Gambar 7 Halaman Hasil Diagnosa

\subsection{Pengujian}

Hasil pengujian sistem dengan metode black box didapatkan sesuai dengan Tabel 7 . 
Tabel 7 Pengujian fungsional sistem dengan black box

\begin{tabular}{|c|c|c|c|c|}
\hline $\begin{array}{l}N \\
0\end{array}$ & Fungsi & Pengujian & $\begin{array}{c}\text { Hasil } \\
\text { diharapkan }\end{array}$ & $\begin{array}{c}\text { Hasil } \\
\text { Penguji } \\
\text { an }\end{array}$ \\
\hline 1 & $\begin{array}{l}\text { Menambahk } \\
\text { an Data } \\
\text { Pasien }\end{array}$ & $\begin{array}{l}\text { Klik } \\
\text { tombol } \\
\text { tambah } \\
\text { pada } \\
\text { halaman } \\
\text { data } \\
\text { pasien, } \\
\text { kemudian } \\
\text { diisikan } \\
\text { data } \\
\text { pasien, } \\
\text { lalu } \\
\text { dilakukan } \\
\text { save. }\end{array}$ & $\begin{array}{l}\text { Akan } \\
\text { bertambah } \\
\text { data } \\
\text { pasien } \\
\text { baru } \\
\text { sesuai } \\
\text { yang } \\
\text { diinputkan }\end{array}$ & Sesua \\
\hline 2 & $\begin{array}{l}\text { Mengubah } \\
\text { Data Pasien }\end{array}$ & $\begin{array}{l}\text { Klik } \\
\text { tombol } \\
\text { edit pada } \\
\text { halaman } \\
\text { data } \\
\text { pasien, } \\
\text { kemudian } \\
\text { diisikan } \\
\text { data } \\
\text { pasien } \\
\text { perbaharu } \\
\text { an yang } \\
\text { diinginan, } \\
\text { lalu } \\
\text { dilakukan } \\
\text { save. }\end{array}$ & $\begin{array}{l}\text { Akan } \\
\text { terjadi } \\
\text { perubahan } \\
\text { data } \\
\text { pasien } \\
\text { baru } \\
\text { sesuai } \\
\text { yang } \\
\text { diinputkan }\end{array}$ & $\begin{array}{l}\text { Sesua } \\
\mathrm{i}\end{array}$ \\
\hline 7 & $\begin{array}{l}\text { Menambahk } \\
\text { an Data } \\
\text { Rule Baru }\end{array}$ & $\begin{array}{l}\text { Klik } \\
\text { tombol } \\
\text { tambah } \\
\text { pada } \\
\text { halaman } \\
\text { data rule, } \\
\text { diisikan } \\
\text { dengan } \\
\text { data rule } \\
\text { antara } \\
\text { hubungan } \\
\text { jenis } \\
\text { gangguan } \\
\text { tidur }\end{array}$ & $\begin{array}{l}\text { Akan } \\
\text { bertambah } \\
\text { data rule } \\
\text { gejala } \\
\text { dengan } \\
\text { gangguan } \\
\text { tidur baru } \\
\text { sesuai } \\
\text { yang } \\
\text { diinputkan }\end{array}$ & Sesua \\
\hline 8 & Diagnosa & $\begin{array}{l}\text { Klik } \\
\text { tombol } \\
\text { diagnosa } \\
\text { pada } \\
\text { tampilan } \\
\text { detail } \\
\text { pasien. }\end{array}$ & $\begin{array}{l}\text { Akan } \\
\text { menampilk } \\
\text { an } \\
\text { halaman } \\
\text { diagnosa } \\
\text { yang berisi } \\
\text { mengenai } \\
\text { gejala- } \\
\text { gejala } \\
\text { yang akan } \\
\text { dipilih oleh } \\
\text { pasien }\end{array}$ & Sesua \\
\hline
\end{tabular}

Hasil pengujian fungsionalitas sistem dengan menggunakan metode black box sebanyak delapan fungsi menyatakan bahwa fungsionalitas sistem dapat berjalan sesuai apa yang direncanakan.

Hasil ujicoba sistem diagnosa gangguan tidur dengan metode Naïve Bayes ini dibandingkan dengan klasifikasi 30 data training terlihat pada Tabel 8.

Tabel 8 Pengujian Validitas Perbandingan Sistem dengan 30 Data Testing

\begin{tabular}{|c|c|c|c|c|}
\hline \multirow[b]{2}{*}{ No } & \multirow[b]{2}{*}{$\begin{array}{c}\text { Gejala } \\
\text { yang } \\
\text { dipilih }\end{array}$} & \multicolumn{2}{|c|}{ Diagnosa } & \multirow[b]{2}{*}{$\begin{array}{c}\text { Valida } \\
\text { si }\end{array}$} \\
\hline & & $\begin{array}{l}\text { Naïve } \\
\text { Bayes }\end{array}$ & $\begin{array}{c}\text { Klasifikas } \\
\text { i } 30 \text { data } \\
\text { testing }\end{array}$ & \\
\hline 1 & $\begin{array}{l}\text { G01,G02 } \\
\text {,G03 }\end{array}$ & Insomnia & Insomnia & Sesuai \\
\hline 2 & $\begin{array}{l}\text { G21, } \\
\text { G22, } \\
\text { G01, } \\
\text { G24 }\end{array}$ & Insomnia & Insomnia & Sesuai \\
\hline 3 & $\begin{array}{l}\text { G21, } \\
\text { G26, } \\
\text { G11, }\end{array}$ & $\begin{array}{l}\text { Hipersom } \\
\text { nia }\end{array}$ & $\begin{array}{l}\text { Hipersom } \\
\text { nia }\end{array}$ & Sesuai \\
\hline 4 & $\begin{array}{l}\text { G11, } \\
\text { G13, } \\
\text { G05, } \\
\text { G08 }\end{array}$ & $\begin{array}{l}\text { Ganggua } \\
\mathrm{n} \text { Jadwal } \\
\text { Tidur }\end{array}$ & $\begin{array}{l}\text { Gangguan } \\
\text { Jadwal } \\
\text { Tidur }\end{array}$ & Sesuai \\
\hline 5 & $\begin{array}{l}\text { G03, } \\
\text { G06, } \\
\text { G18 }\end{array}$ & $\begin{array}{l}\text { Hipersom } \\
\text { nia }\end{array}$ & Insomnia & Tidak \\
\hline 6 & $\begin{array}{l}\text { G07, } \\
\text { G08, } \\
\text { G10, } \\
\text { G18 }\end{array}$ & $\begin{array}{l}\text { Narkolep } \\
\text { si }\end{array}$ & Narkolepsi & Sesuai \\
\hline 7 & $\begin{array}{l}\text { G12,G01 } \\
\text { 4,G017, } \\
\text { G31 }\end{array}$ & $\begin{array}{l}\text { Teror } \\
\text { Tidur }\end{array}$ & $\begin{array}{l}\text { Mimpi } \\
\text { Buruk }\end{array}$ & Sesuai \\
\hline 8 & $\begin{array}{l}\text { G15, } \\
\text { G21, } \\
\text { G30 }\end{array}$ & $\begin{array}{l}\text { Mimpi } \\
\text { Buruk }\end{array}$ & $\begin{array}{l}\text { Mimpi } \\
\text { Buruk }\end{array}$ & Sesuai \\
\hline 9 & $\begin{array}{l}\text { G17, } \\
\text { G12, } \\
\text { G31 }\end{array}$ & $\begin{array}{l}\text { Teror } \\
\text { Tidur }\end{array}$ & $\begin{array}{l}\text { Teror } \\
\text { Tidur }\end{array}$ & Sesuai \\
\hline 10 & $\begin{array}{l}\text { G14, } \\
\text { G18, } \\
\text { G30 }\end{array}$ & $\begin{array}{l}\text { Narkolep } \\
\text { si }\end{array}$ & Narkolepsi & Sesuai \\
\hline
\end{tabular}

Hasil diagnosis yang diperoleh dari perhitungan naïve bayes pada sistem ini dibandingkan dengan hasil diagnosis klasifikasi 30 data training terdapat 8 data benar sehingga akurasi dari sistem dapat dihitung dengan menggunakan persamaan berikut,

$$
\begin{aligned}
& \text { akurasi }=\frac{\text { jumlah data benar }}{\text { jumlah data keseluruhan }} \times 100 \% \\
& \text { akurasi }=\frac{8}{10} \times 100 \%
\end{aligned}
$$

Dari perhitungan akurasi dihasilkan akurasi dari sistem diagnosis gangguan tidur dengan metode Naïve Bayes sebesar $80 \%$ sehingga metode Naïve Bayes dapat diimplementasikan untuk melakukan diagnosis jenis gangguan tidur. 


\section{PENUTUP}

\subsection{Kesimpulan}

Berdasarkan penelitian yang telah dilakukan, maka dapat diambil kesimpulan diantaranya :

1. Metode Naïve Bayes berhasil diterapkan pada sistem analisis diagnosa jenis gangguan tidur. Metode Naïve Bayes diterapkan dengan cara memberikan knowledge base atau aturan-aturan yang digunakan pada proses analisa gejala pasien.

2. Akurasi pengujian sistem implementasi metode Naïve Bayes untuk diagnosis jenis gangguan tidur sebesar $80 \%$ dimana hal tersebut dikarenakan metode naïve bayes melakukan perhitungan berdasarkan input gejala yang dipilih terhadap data training.

3. Berdasarkan uji fungsi dan validitas pada sistem didapatkan bahwa dari delapan uji fungsi yang dilakukan pada sistem menggunakan black box menghasilkan fungsi pada sistem berjalan sesuai dengan skenario, sedangkan uji validitas sistem dengan metode perhitungan naïve bayes didapatkan bahwa hasil diagnosis sesuai dengan diagnosis pakar atau fakta.

\subsection{Saran}

Setelah sistem ini dibuat serta dilakukan uji fungsional sistem dan validitas, terdapat saran yang dapat diterapkan pada penelitian sejenis selanjutnya yaitu:

1. Pengetahuan atau knowledge base dari sistem ini dapat semakin diperkaya dengan penambahan kompleksitas gejala yang diberikan, agar dapat memberikan penjelasan informasi kepada pengguna yang lebih komplek.

2. Pengembangan aplikasi serupa dapat dibuat dengan penambahan aktor baru yaitu masing-masing pasien. Sehingga warga disekitar puskesmas karangmalang dapat mengakses sistem ini secara online dan dapat melakukan analisis diagnosis gangguan tidur yang dialami secara mandiri.

\section{DAFTAR PUSTAKA}

[1] A. Fadhli Almuiin and Miftachuniam, "Aplikasi penentuan jenis penyakit yang memungkinkan bisa diterapi dengan bawang merah dengan menggunakan metode naïve bayes," Jurnal IImiah Teknologi dan Informasi ASIA, pp. 34-44, 2015.

[2] Departemen Kesehatan, Pedoman Penggolongan dan Diagnosis Gangguan Jiwa di Indonesia III, Jakarta: Departemen Kesehatan, 1993.

[3] N. Rifqi, W. Maharani and Shaufiah, Analisis Dan Implementasi Klasifikasi Data Mining Menggunakan Jaringan Syaraf Tiruan Dan Evolution Strategis, Bali: Konferensi Nasional Sistem dan Informatika, 2011.

[4] W. Setiawan and S. Ratnasari, "Sistem Pakar Diagnosa Penyakit Mata Menggunakan Naive Bayes Classifier," Seminar Nasional Sains dan Teknologi, pp. 1-6, 2014.

[5] R. A. Saputra, "Komparasi Algoritma Klasifikasi Data Mining Untuk Memprediksi Penyakit Tuberculosis (Tb):Studi Kasus Puskesmas Karawang Sukabumi," Seminar Nasional Inovasi dan Tren (SNIT), pp. 1-8, 2014.

[6] A. S. Rosa and M. Shalahudin, Rekayasa Perangkat Lunak Terstruktur dan Berorientasi Objek Edisi Revisi, Informatika, 2018. 